\title{
Front Matter: Volume 11912
}

, "Front Matter: Volume 11912," Proc. SPIE 11912, Pacific Rim Laser Damage 2021: Optical Materials for High-Power Lasers, 1191201 (11 August 2021); doi: $10.1117 / 12.2607793$

SPIE Event: Pacific Rim Laser Damage 2021: Optical Materials for High Power Lasers, 2021, Hangzhou, China 


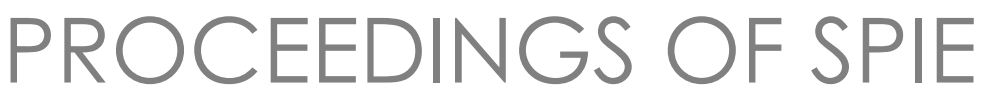

\section{Pacific Rim Laser Damage 2021: Optical Materials for High-Power Lasers}

\section{Yuchuan Shao}

Editor

23-25 May 2021

Hangzhou, China

Organized by

Shanghai Institute of Optics and Fine Mechanics

SPIE

Sponsored by

Chinese Laser Press

Hangzhou Institute for Advanced Study

Published by

SPIE 
The papers in this volume were part of the technical conference cited on the cover and title page. Papers were selected and subject to review by the editors and conference program committee. Some conference presentations may not be available for publication. Additional papers and presentation recordings may be available online in the SPIE Digital Library at SPIEDigitalLibrary.org.

The papers reflect the work and thoughts of the authors and are published herein as submitted. The publisher is not responsible for the validity of the information or for any outcomes resulting from reliance thereon.

Please use the following format to cite material from these proceedings:

Author(s), "Title of Paper," in Pacific Rim Laser Damage 2021: Optical Materials for High Power Lasers, edited by Yuchuan Shao, Proc. of SPIE 11912, Seven-digit Article CID Number (DD/MM/YYYY); (DOI URL).

ISSN: 0277-786X

ISSN: 1996-756X (electronic)

ISBN: 9781510646834

ISBN: 9781510646841 (electronic)

Published by

SPIE

P.O. Box 10, Bellingham, Washington 98227-0010 USA

Telephone +1 3606763290 (Pacific Time)

SPIE.org

Copyright @ 2021 Society of Photo-Optical Instrumentation Engineers (SPIE).

Copying of material in this book for internal or personal use, or for the internal or personal use of specific clients, beyond the fair use provisions granted by the U.S. Copyright Law is authorized by SPIE subject to payment of fees. To obtain permission to use and share articles in this volume, visit Copyright Clearance Center at copyright.com. Other copying for republication, resale, advertising or promotion, or any form of systematic or multiple reproduction of any material in this book is prohibited except with permission in writing from the publisher.

Printed in the United States of America by Curran Associates, Inc., under license from SPIE.

Publication of record for individual papers is online in the SPIE Digital Library.

\section{SP|E. DIGITAL}

Paper Numbering: A unique citation identifier (CID) number is assigned to each article in the Proceedings of SPIE at the time of publication. Utilization of CIDs allows articles to be fully citable as soon as they are published online, and connects the same identifier to all online and print versions of the publication. SPIE uses a seven-digit CID article numbering system structured as follows:

- The first five digits correspond to the SPIE volume number.

- The last two digits indicate publication order within the volume using a Base 36 numbering system employing both numerals and letters. These two-number sets start with 00, 01, 02, 03, 04, 05, 06, 07, 08, 09, 0A, OB ... 0Z, followed by 10-1Z, 20-2Z, etc. The CID Number appears on each page of the manuscript. 


\section{Contents}

$\checkmark \quad$ Conference Committee

SESSION 1 PACIFIC RIM LASER DAMAGE 2021: OPTICAL MATERIALS FOR HIGH POWER LASERS

1191202 The influence of laser irradiation conditions on the bulk damage of JGS1 fused silica [1 1912-3]

1191203 Study on damage of $\mathbf{M g F}_{\mathbf{2}}$ window irradiated by $\mathbf{1 9 3} \mathbf{n m}$ ultraviolet excimer laser [1 1912-5]

$1191204 \quad$ Photodarkening in $\mathrm{Pr}^{3+}$-doped silicate glasses and fibers [11912-6]

1191205 The simulation of thermal deformation on lightweight optics with thick coatings [11912-7]

1191206 The photo-thermal absorbing influence on introducing laser-damaging of the fused silica [11912-9]

1191207 Research on the properties of $\mathrm{HfO}_{2}$ optical films prepared with APS assisted electron beam evaporation deposition [11912-10]

1191208 Influence of organic solvents on fused silica components with different high transmission films [11912-12]

1191209 A detection method of weak and small defects based on fluorescence imaging technology [11912-13]

$119120 \mathrm{~A} \quad$ Study on influence of laser parameters on temperature field of PbS detector irradiated by 2.79um mid-infrared laser [11912-14]

$11912 \mathrm{OB} \quad$ Study on $\mathrm{HfO}_{2} / \mathrm{SiO}_{2}$ high reflective film damage induced by $248 \mathrm{~nm} \mathrm{UV}$ excimer laser [11912-15]

$119120 \mathrm{C}$ Influence of the space radiation environment model uncertainty on the solar absorption evaluation of ITO/Kapton/Al film [11912-16]

11912 OD Effect of material outgassing and contamination deposition induced by vacuum and temperature on spacecraft optical components [11912-20]

11912 OE Synergistic effect of electron and proton on the mechanical properties of polyimide films [11912-21]

11912 OF Research on optical non-uniformity and stability of $\mathrm{TiO}_{2}-\mathrm{SiO}_{2}$ glass [1 1912-22]

$119120 \mathrm{E}$ Effect of titania dopant on optical performance of silica glass [11912-23] 
$11912 \mathrm{OH}$ Design and fabrication of the broad angular spectrum dichroic mirror [11912-24]

$1191201 \quad$ High efficiency multiplexed volume Bragg gratings for angle deflection at 1064nm [11912-28]

$119120 \mathrm{~J} \quad$ Load capacity prediction of monocrystalline silicon mirror based on multimodal coupling characterization [11912-29]

11912 OK Fabrication and analysis of broadband chirped volume Bragg grating [1 1912-30]

$11912 \mathrm{OL}$ Experimental research of ultraviolet radiation enhancement effect on molecular contamination of sensitive optical device [11912-31]

$11912 \mathrm{OM} \quad$ Damage of $\mathrm{SiO}_{2}$ film under low-energy proton irradiation and laser irradiation [1 1912-32]

11912 ON Ni micro-nano structures fabrication through electroplating [11912-33]

1191200 Nanosecond laser damage characteristics of multilayer dielectric films and gratings [11912-37]

11912 OP Electric field enhancement effect of substrate surface scratches in 1064nm high-reflection coating [11912-39]

$119120 Q \quad$ Intelligent laser machining system for multi-function processing of superhard materials [11912-43]

11912 OR Study of micron-scale defects in optical coatings for high-power lasers deposited by ion beam sputtering [11912-44] 


\title{
Conference Committee
}

\author{
Conference Chairs
}

Jianda Shao, Shanghai Institute of Optics and Fine Mechanics,

CAS (China)

Takahisa Jitsuno, Osaka University (Japan)

Wolfgang Rudolph, The University of New Mexico (United States)

Technical Program Committee

Ioan Dancus, Horia Hulubei National Institute of Physics and Nuclear Engineering (Romania)

Efim A.Khazanov, Institute of Applied Physics (Russia)

Zhi M.Liao, Lawrence Livermore National Laboratory (United States)

Yongfeng Lu, Univsersity of Nebraska-Lincoln (United States)

Jean-Yves Natoli, Institute Fresnel (France)

Valdas Sirutkaitis, Vilnius University (Lithuania)

MJ Soileau, University of Central Florida (United States)

Christopher J.Stolz, Lawrence Livermore National Laboratory (United States)

Koji Sugioka, RIKEN (Japan)

Takunori Taira, Institute for Molecular Science (Japan)

Mauro Tonelli, Università di Pisa (Italy)

Zhouling Wu, ZC Optoelectronic Technologies Ltd. (China)

Qiao Xu, China Academy of Engineering Physics (China)

Organizing Committee

Ya Cheng, Shanghai Institute of Optics and Fine Mechanics, CAS (China)

Yaping Dai, China Academy of Engineering Physics, CAS (China)

Hongbo He, Shanghai Institute of Optics and Fine Mechanics, CAS (China)

Guixue Huang, National High Technology Research and Development (China)

Yuxin Leng, Shanghai Institute of Optics and Fine Mechanics, CAS (China)

Liejia Qian, Shanghai Jiao Tong University (China)

Kui Yi,Shanghai Institute of Optics and Fine Mechanics, CAS (China)

Weiping Wu, Shanghai Institute of Optics and Fine Mechanics, CAS (China)

Long Zhang, Shanghai Institute of Optics and Fine Mechanics, CAS (China) 
Proc. of SPIE Vol. 11912 1191201-6

Downloaded From: https://www.spiedigitallibrary.org/conference-proceedings-of-spie on 25 Apr 2023 Terms of Use: https://www.spiedigitallibrary.org/terms-of-use 